\title{
Qualifying the Boom-Bust Paradigm: An Examination of the off-Shore Oil and Gas Industry
}

\author{
Timothy C. Brown ${ }^{1}$, William B. Bankston ${ }^{2}$, Craig J. Forsyth ${ }^{3}$, Emily R. Berthelot ${ }^{4}$ \\ ${ }^{1}$ University of Houston, Houston, USA; \\ ${ }^{2}$ Louisiana State University, Baton Rouge, USA; \\ ${ }^{3}$ University of Louisiana, Lafayette, USA; \\ ${ }^{4}$ University of Houston-Downtown, Houston, USA. \\ Email: tcbrown2@mail.uh.edu \\ Received March 23 ${ }^{\text {rd }}$, 2011; revised April 27 $7^{\text {th }}$, 2011; accepted May 31 ${ }^{\text {st }}, 2011$.
}

\begin{abstract}
The oil industry is seen as being similar to other mining activities in having a cycle of expansion and subsequent contraction. Previous literature suggests this cycle leads to boomtown communities. Furthermore, the oil and gas industry is often seen as a having primarily negative social effects on the communities it invades. The present research takes an in-depth look at the small South Louisiana community of St. Mary Parish; an area with economic roots in such extraction enterprises as lumber, fishing and later, oil. Positive attributes of the presence of the oil and gas industry are identified, namely-sustainability and increased life chances of local residents. Due to methodological limitations previous research might have been unable to holistically view the off-shore oil industries impacts on communities. This paper concludes that the paradigmatic usage of the NEPA boomtown model is inapt for the study of the Gulf off-shore oil industry.
\end{abstract}

Keywords: Social Change, Boom-Town Model, Social Impact Assessment, Oil and Gas, Qualitative Research

\section{Introduction}

The offshore oil industry is one of the largest industries in the gulf area. Within 40 years of its inception, the industry provided direct employment to 41,798 residents of Louisiana. The reach of the oil industry extends even farther than those under direct employment. By 1981 the industry led to the creation of over 80 thousand other jobs servicing the extraction of off-shore oil (Tolbert II, 2006). With the majority of off-shore oil leases belonging to Texas and Louisiana, the impact of this industry on these states' communities is unquestionable.

A great deal of academic interest has been aimed at the social, cultural and economic impact of the oil and gas industry. Often the oil and gas industry is seen as having negative social effects within this literature. However, the present research was conceived when an in depth inductive look was placed on the relatively small South Louisiana community of St. Mary Parish. St. Mary parish, with its economic roots in such extraction enterprises as lumber, fishing and presently oil, began to show a positive attribute of the presence of the oil and gas industry-sustainability. With its lumber exhausted, sugar cane farming delegated to South America, and the rise of Asian shrimp markets, St. Mary parish likely would have experienced great economic decline if it had not been for the development of off-shore oil and gas and its associated service activities. However, this positive aspect of off-shore oil in this community has often been unidentified in previous research. Due to methodological limitations previous research might have been unable to holistically view the off-shore oil industries impacts on communities. The use of social impact assessment models that were designed to assess different forms of energy extraction might have led to misleading results which might be avoided by utilizing methodology more tailored to the off-shore oil industry.
The oil industry is similar to other mining activities in having a cycle of expansion and contraction dependent on levels of supply and demand. Previous literature suggests this cycle leads to boomtown communities (Murdock et al., 1984; Summers \& Selvik, 1982). These boomtown communities witness explosions of growth during the commissioning and extraction phases. These phases are synonymous with population and infrastructure growth. Typically, this growth is short lived and when the extraction activity is decommissioned all positive aspects fall to negative consequences. Whatever growth the community witnessed is truncated. These communities witness a vast outmigration of workers and infrastructure leaving them often in economic decline.

Arguments towards the misuse of boomtown models to explain the off-shore oil industry have appeared in recent literature (Gramling \& Brabant, 1986; Luton \& Cluck, 2002). It is argued that disparities exist between the boomtown model of effects and the realities of the off-shore oil industry. The first dramatic disparity is of the sheer size of the off-shore oil industry in comparison to individual mining operations. Very little, if any, of these mining operations encompassed areas as vast as the gulf region. This is not only spatial in nature. The complexity and number of separate industries involved in oil extraction in the gulf dwarfs the majority of other energy extraction operations. Furthermore, the time span of oil extraction in the gulf has been over several decades and has not shown the finite period of time usually identified in boomtown models.

The disparities between the boomtown model's assumptions and reality have lead to possible distortions in research findings. The inherent tendency of this model to concentrate on the proposed negative effects of energy extraction operations on communities has led scholars to translate these negative outcomes to communities where they might not necessarily fit. The 
utilization of the boomtown model led to conclusions that the industry was leading to ultimately negative economic and social outcomes for community residents. Yet, from talking to community residents and leaders, it became clear this perception was not shared by those in the community. This has led to a call for a new technique in studying the social impact of the oil industry, particularly in the Gulf of Mexico region.

This research aims to evaluate the effects of the off-shore oil industry on the community in which it resides. But, this study has several significant changes from previous research on this topic. First, it was not committed to the use of a boomtown model that may be ill fitted to identify long term industry effects. Rather it utilized a "diversity of effects" model that takes into account the complexity of the off-shore oil industry and those communities it inhabits. It was argued that research should depart from the previous paradigmatic view of the nature of gulf off-shore oil operations and utilize a model that analytically splits the industry into different dimensions and calls for research of these specific categories (Luton \& Cluck, 2002). In particular, this research attempted to investigate the social capital consequences of the off-shore oil industry for a specific host community.

Second, this study used a qualitative methodological framework with the goal of developing an in-depth-explanation of the industry and its effects in terms of the experiences of those that lived them. The majority of previous literature on this topic has utilized quantitative methods. The use of qualitative methods may lead to unique or possible new findings (Forsyth, Luthra, \& Bankston, 2007). In particular, the life history method is thought to be important method to use when an area of study has grown stagnant by virtue of its quantified detail (Becker, 1970).

\section{Review of Literature}

\section{Consequences of Community Growth}

Sociology has a long tradition of investigating the causes and consequences of social change (Parsons \& Shils, 1951; Toennies, 1963). The positive or negative social impact of community growth has long been pondered by sociologists since the inception of the discipline. Spurred by the industrial revolution many have investigated whether or not rapid growth is beneficial for the communities experiencing it. Classic theorists, such as Durkheim and Toennies, suggested that rapid growth may result in substantial disruption for community members (Freudenburg, 1984). Durkheim posited that one possible outcome of rapid growth is states of anomie felt by residents. This state of a lowered normative consensus is brought upon by community growth contributing to the individual's world becoming more complex and less predictable.

Contemporary social theory also comments on the role of social change on community outcomes. Shaw and McKay's (1969) theory of social disorganization states that societies (neighborhoods more specifically) rely on a normative consensus on common goals in order to regulate behavior. However, they posit that social change, including growth, will undermine this normative consensus and lead to negative communal outcomes. Such variables as poverty, racial heterogeneity, and high levels of mobility are posited to break down this normative consensus.

Similar research adds upon this theoretical model emphasizing the importance of residential stability on community cohe- sion and ultimate ability to engage in informal social control (Kasarda \& Janowitz, 1974; Bursick \& Grasmick, 1993)

The off-shore oil industry has brought about a tremendous amount of change to the communities in which it resides. The sheer mass of the industry has brought large in-migrations as well as large exoduses from many communities. These communities have been impacted and changed in a variety of ways. Certain lines of sociological thought such as social disorganization or the decline of community thesis would predict many negative effects to befall these communities.

However, research on the effects of the off-shore oil industry on communities in the gulf region has been divided. Some argue that the off-shore oil industry, like other extraction industries, will be detrimental to the region in the long run (Seydlitz, Laska, Spain, Triche, \& Bishop, 1993; Seydlitz, Jenkins et al., 1995). Seydlitz et al. (1995) point to various literature that suggest negative outcomes of the off-shore oil industry such as: locals not benefiting from employment due to low levels of human capital; increased strain on local infrastructure; elevated unemployment rates and increases in poverty during the height of mineral extraction.

While other literature indicates positive community effects of the off-shore oil industry. Such positive effects as lowered demands for welfare and food stamps, increased avenues for status attainment and other positive economic situations have been seen during the boom periods of extraction (Forsyth, Luthra, \& Bankston, 2007; Brabant, 1993). Another study discussed the ability of the oil and gas industry to buffer communities undergoing industrial restructuring (Tolbert II, 2006).

Forsyth, Luthra and Bankston (2007: p. 297) found the vast majority of respondents saw positive effects of the oil industry on community growth. The individuals interviewed had developed specific caveats for acknowledging their convictions, but very few of these individuals perceived the oil industry to be a source of major disruption, and most saw the consequences as being positive. They conclude if one takes the perspective that the social construction of problems may be found in the process of social actors creating causal stories involving blame or intent and their image of consequences (Stone, 1989), their data suggests a rather broad range of definitions of the effect of off-shore development on community problems, with the most typical interpretative themes offering an image of long-term positive community gains.

A possible explanation for the disparity in the literature lies in the model utilized by previous scholars to investigate growth brought upon by the Gulf oil industry may be inappropriate (Gramling \& Brabant, 1986; Luton \& Cluck, 2002). The following section will give a comprehensive review of the literature on the models utilized for social impact assessment research dealing with off-shore oil extraction.

\section{History of Social Impact Assessment and the Gulf's Offshore Oil Industry}

Mineral extraction operations effects on communities have been widely researched and criticized. However, research on the socioeconomic effects of the Gulf of Mexico's offshore petroleum industry was relatively non-existent until the collapse of petroleum prices in 1986.

The National Environmental Policy Act (NEPA) was initiated to identify, examine, and resolve adverse environmental 
and socioeconomic consequences of government land actions (Luton \& Cluck, 2002). The Environmental Studies Program (ESP) which is overseen by the Mineral Management Service (MMS) funds research regarding the Outer Continental Shelf (OCS) petroleum operations. Previous to 1986 little research regarding socioeconomic effects of OCS was conducted. Instead research emphasized oceanographic and ecologic matters. The reasoning for this decision was based on the argument that the oil industry's long history in the gulf and it's well developed infrastructure and workforce would make social impacts of offshore development difficult to identify.

However, after 1986 a new interest into the socioeconomic effects of OCS operations developed. The 1986 collapse of petroleum prices and more importantly its possible adverse effects on surrounding communities fueled this interest. The low volume of research by the ESP regarding the socioeconomic component of OCS began to come under heavy criticism. Scholars emphasized that the same 100 year history of industry operations in the Gulf previously used to argue against socioeconomic research should be reevaluated and utilized to study petroleum's social and economic effect (Luton and Cluck 2002). The pre-existing social impact assessment model, the NEPA boomtown model, was used as a framework to study the Gulf's offshore petroleum industry (Seydlitz et al., 1993; Seydlitz \& Laska, 1994; Seydlitz et al., 1995).

\section{Description of the Boomtown Model}

The boomtown model was the first social impact assessment model utilized in researching offshore petroleum extraction, and for 20 years has been the predominate model used for energy-related projects. The boomtown model originated from community impact studies conducted in the late 1970's and early 1980 's that addressed large, governmental regulated extraction projects mostly in rural areas of the western United States. (Gramling \& Brabant, 1986).

The model was shaped by the shared characteristics and situations recognized when large complex extraction projects are constructed near small, rural, isolated, homogenous, agricultural-based economies. Since these projects and the changes they produced only existed for a limited amount of time within the communities, they were referred to as boomtowns. The typical lifespan of these projects would entail a short construction phase with high levels of employment and heavy demands on the community and its infrastructure. Once the construction was complete it would go into operation which lasted longer than the construction yet demanded fewer and more specialized workers. Lastly when extraction was complete a decommissioning phase brought the close of the project (Gramling \& Brabant, 1986).

The labor demands of the projects were well beyond what the community could supply. The small population of the rural communities as well as the insufficient human capital of their residents postulated that the majority of new jobs (esp. more specialized and technical employment) would not be filled by local residents. This shortage of capable workers led to a large in-migration of workers into these rural communities. However, this in-migration was followed by an out-migration of workers from the community after completion of the decommissioning phase (Gramling \& Brabant, 1986; Seydlitz et al., 1995; Luton \& Cluck, 2002).
This labor demand and its consequential demographic effects are crucial to the boomtown model. The rapid population growth and later decline are illustrated by the model as the primary cause of positive and negative economic; infrastructural; fiscal; and lastly social/cultural impacts occurring in these rural communities due to the short presence of large extraction projects. The models use of demographic effects as causal mechanisms to social/cultural topics may not be as valid as the other three impact categories because even though "these topics do share one commonality; none fits easily into other classic SIA impact categories because each has a complex and, often, unclear or uncertain relationship to demographic change” (Luton \& Cluck, 2002). While some of the social and cultural impacts documented are positive, such as alternative pathways to new social status introduced to residents, most of the impacts are negative. These documented negative impacts are attributed to the rapid in and out migration experienced within the communities after the closure of the project in accordance with social disorganization literature (Seydlitz et al., 1993, 1995).

Predominate use of the boomtown model in research dealing with extraction based projects is argued by scholars to have formulated a paradigm in literature (Gramling \& Brabant, 1986; Luton \& Cluck, 2002). This argument suggests the possibility that a coherent scientific tradition has been put in place that leads the majority of research to narrowly focus on demographic and disruptive effects as causal variables for all impacts, usually negative, seen within these communities (see Seydlitz \& Laska, 1994). It can be that the aforementioned demographic effects are not seen throughout all communities where extraction based projects are initiated which negates the use of the model in these areas. However, due to the paradigmatic effect of the boomtown model many scholars still strive to use this perspective in these areas even when it may not be appropriate (Wilkinson, Thompson, Reynolds, \& Ostresh, 1982).

\section{Contrasts between the Boomtown Model and Gulf Realities}

Certain aspects highlighted by the boomtown model are argued incompatible with the Gulf's petroleum industry. First, other extraction industries are often fully dependent upon the singular extraction company; however, the Gulf is inhabited by various communities each hosting a different mix of oil-related business. Off-shore extraction calls for platforms, exploratory rigs, boats, among other equipment. This service industry leads to a diverse geographically fixed labor force weakening any tendencies to create boomtowns (Luton \& Cluck, 2002). Furthermore, this industrial diversification provides a safety net when eventual 'busts' occur within the gulf oil industry (Tolbert II, 2006). Some communities even fared better during 'bust' periods due to their service economies not being completely dependent upon extraction (Seydlitz \& Laska, 1995).

The exclusivity of the boomtown model reviewing projects being introduced to small, rural, isolated areas also might be unsuitable. Southern Louisiana's off-shore oil industry began to grow rapidly in the 1960's. These demographic changes were more complex than the simple construction phase of the boomtown model would predict. Growth was not only seen in the coastal parishes heavily involved with supporting offshore activities but also in urbanized and industrialized areas due to real economic growth driven in large part by the oil industry and 
associated refining and petrochemical industries. The industry's demographic consequences had ceased to be the kind of localized or community-centered phenomena addressed by boom town model (Luton \& Cluck, 2002).

The shortened time span model of the boomtown is also argued to be flawed when discussing the Gulf. This model looks at projects as new and foreign to the community it enters. However, in the Gulf the oil industry is decades old which has made it familiar to the residents. Due to this long presence of oil industries in the gulf, the region's labor force has adapted to the industry. Thus the industry's technologies are familiar to the rural population which allows rural residents to work in jobs related to all phases of the industry. This is contrary to the boomtown model's predictions of rural residents only being utilized during the construction phase.

Last, the boomtown model's basis of looking at a single project may not be applicable when researching the complex assortment of petroleum related activity that occurs in the Gulf region. Unlike boomtown models, the offshore oil "industry does not appear in communities as something new with discrete phases but rather as a continuation of business, and social and economic effects related to changes in the magnitude and mix of this commercial continuity” (Luton \& Cluck, 2002: p. 17).

\section{Alternative Paradigm for Social Impact Assessment Based on Diversity of Effects}

These arguments against the Boomtown models have brought arguments for the use of a new strategy of measuring impact (Innes \& Booher, 2000; Jackson et al., 2004) which incorporates the diversity of effects that the gulf oil industry has on communities (Luton \& Cluck, 2002; Gramling \& Brabant, 1986). The base of the argument states that even though communities that are impacted by the Gulf oil industry are changing, the industry is just one of many causes of most effects. Thus the new strategy's challenge is to identify the oil industry's share of impact on social change instead of being identified as the sole cause as is dictated by boomtown models.

Due to the complexity of this challenge it is argued that the strategy should begin by addressing each topic of effect separately utilizing logic and findings from relevant academic fields rather than the topic's role in an a priori model (Luton \& Cluck, 2002). This empirical approach is fostered with the aim of providing a more useful foundation on which to build future monitoring and mitigation efforts.

\section{Methodology}

A qualitative methodological framework was used for the present research. The research was conducted in Morgan City, Louisiana and nearby communities within St. Mary Parish. Individual level data was collected using face to face interviews with knowledgeable informants. A non-probability sample of informants was obtained through snow ball sampling. The data gathered was then analyzed through the use of analytic induction.

\section{Sampling Techniques}

The research identified and interviewed key informants in the Morgan City, Amelia, Patterson, Berwick, Bayou Vista, Frank- lin, Lydia, Baldwin, and Charenton areas of Louisiana. Sampling was varied across locales with extensive sampling in some areas and less extensive in others. The area of Morgan City was over sampled because it is the largest city in the parish and historically has been the hub of the East St. Mary Parish region and the industrial/oil center of the parish.

As Tolbert et al. (2002) notes community studies often utilize a non-probability design in aims of locating a more knowledgeable sample. This is done because the sampling design is preferable to probability sampling in small studies, especially where the probability of selecting an element from the universe that is knowledgeable on a certain issue is unknown. In this case, the respondents were required to have some knowledge of the oil industry in the area. The technique of snowball sampling is utilized for this research. In this technique key members of the population are selected and then asked to recommend others for interviewing, and each of the subsequently interviewed participants are asked for further recommendations which develops an ever-increasing accumulation of subjects (Babbie, 2004). The initial sample size for the study was 175 respondents interviewed. However after the data was cleaned and unsatisfactory interviews were removed the final sample size was $156^{1}$.

\section{Snowball Sampling Process}

While snowball sampling is better suited to locate knowledgeable informants when the population is not well known, it does have limitations. One limitation lies in possible selection bias on part of the respondents and researchers. In other words, original respondents may choose individuals who have similar opinion on the topic under study as themselves providing for a very homogenous sample. Steps were taken to try to provide for as heterogeneous of a sample as possible both demographically as well as their relationship to the off-shore oil industry. The sampling process started with members of the Morgan City Historical Society and personal contacts in the community. From this group a sample of over 100 individuals who have long term familiarity with the community were obtained. Subjects involved in civic, religious, educational, business, political, and fraternal organizations were sought out to appropriately answer what effects the petroleum industry had on the social fabric and capital of the area. Since these groups tend to be dominated by upper middle-class families and individuals, methods were taken to attain greater class/occupational range in the sample by including working class individuals/families in the sample. The research also attempted to utilize sampling methods to obtain informants from populations of specific interests, particularly minorities, to determine their perceptions of the long-term community impacts of the petroleum industry, and their involvement in it. Other means were taken to provide the most generalized sample frame as possible such as sampling respondents from as large of a geographical span as possible. Also, respondents were asked to name as many possible potential informants as they could and furthermore asking them to provide subjects who do not work in the oil industry along with those who do. The sampling process was terminated when themes became salient and saturation had occurred.

\footnotetext{
${ }^{1}$ Incomplete interviews was the sole reason for the exclusion of the nineteen interviews from the final sample.
} 


\section{Descriptive Statistics of Sample}

The demographic layout of St. Mary parish presents a picture from which one can compare the studies' sample statistics. The median age of St. Mary Parish residents is 34. The median age for Morgan City is close at 36. Both St Mary Parish and Morgan City according to the 2000 U.S. Census had populations that were 52 percent female and 48 percent male. Morgan City as well as the parish it resides it are predominantly white with Morgan City showing 62 percent of its inhabitants as white and 71 percent for St. Mary Parish overall.

This sample differs from the population of St. Mary Parish in age, sex and race. The demographic statistics are a little higher for all categories. The mean age of the sample is 58 years old with a standard deviation of 14 years. 68 percent of the informants in the sample are male and 92 percent of those are white. The other 8 percent of the sample are African-American. Further descriptive statistics of the sample include those respondents who are natives to the area and if they are employed in the oil industry, in any fashion. 30 percent of the respondents were employed directly with the oil industry and 67 percent were natives of the area. (Table 1)

\section{Interview Technique}

Face to face interviewing was used to gather the respondent's familial history. These social biographies described how inter-generational life experiences were affected by the oil industry. Open ended focus interviews were conducted geared toward constructing social biographies of individuals and their families who have lived with and through the range of effects the impact of oil has had. This method does pose problems since many times during data collection unique topics appear that were not anticipated early in the interview structuring process (Jacobs, 2000: p. 15). However, the semi structured element of the interviews allows for saturation of the research protocol through enabling the researcher fluidity through the interview process. Lastly, issues pertaining to the validity of respondent's answers are not foreseen to be a problem for this study based on the fact that there will not be any controversial questions.

The face to face interviews consisted of discussions with informants who were given direction by interviewers to discuss topics regarding social mobility. Data was explored through the use of "thick descriptions" (Geertz, 1973), letting the respondents speak for themselves, and summarizing their perceptions. These conversations/interviews lasted an average of approximately 1.5 hours, and ranged from 45 minutes to 5 hours.

Table 1:

Descriptive statistics of sample.

\begin{tabular}{|c|c|c|c|c|c|}
\hline & $\mathrm{N}$ & Minimum & Maximum & Mean & Std. Deviation \\
\hline Age & 156 & 24.00 & 92.00 & 58.2244 & 14.51876 \\
\hline Sex & & & & & \\
\hline $\begin{array}{l}(0=\text { Female } \\
1=\text { Male })\end{array}$ & 156 & .00 & 1.00 & 6795 & .46818 \\
\hline $\begin{array}{l}\text { Race } \\
(0=\text { non-white; } 1= \\
\text { white })\end{array}$ & 156 & .00 & 1.00 & .9231 & .26733 \\
\hline $\begin{array}{l}\text { Native to the area } \\
(0=\text { no; } 1=\text { yes })\end{array}$ & 156 & .00 & 1.00 & .6731 & .47060 \\
\hline $\begin{array}{l}\text { Oil job } \\
(0=\text { no; } 1=\text { yes })\end{array}$ & 156 & .00 & 1.00 & . 3013 & .46029 \\
\hline Valid N & 156 & & & & \\
\hline
\end{tabular}

\section{Findings}

\section{Industrial diversification}

The key difference that may separate the empirical reality of the gulf oil industry from the communities described by boomtown studies is the industrial diversification seen within many of the areas dependent upon off-shore oil extraction. While these communities are dependent upon the extraction of off-shore oil they are not dependent upon one singular company. Instead there is often a plethora of different businesses incorporated within the community.

36 year old, white male, fabrication industry: "I would say that oil field and support service are still the majority employer within the parish. Most people are either directly tied to it or maybe one degree removed from being directly tied to the oil field. That is still the biggest economic engine that we have in the parish."

Furthermore, as the above quote illustrates, these companies often are locally owned and operated small sized firms which service the oil field economy. This diversification has allowed the communities to branch out and not be totally dependent upon one particular company or even industry. This has subsequently led to an increased ability for community sustainability. The following quote from a prominent resident of the community describes how the industrial nature of the area allows for the community to not be fully dependent upon the status of one industry or company.

54 year old, white male, newspaper editor: "I am all to happy to run and get the copy of the paper that [was run] were the entire front half of the front page was dedicated to an artist rendering of the new multimillion dollar facility that [an oil service company] is going to build on railroad avenue on the water...There are other companies, service companies, that have made long term commitments to the area also...I think there is a lot more opportunity here now than there has been in the last I will say 20 years. Another company that comes to mind told me that by the end of next year it is not out of the realm of possibilities that they will have over 400 people working again. Maybe even possibly closer to 600 now that they have purged themselves of an exclusive arrangement [with a large oil company]. Which I thought was all their eggs in one basket. They are going to start building back on the basics that put them on the map."

While the diverse nature of the industrial landscape is important to the sustainability of these communities what may be more important, as the above respondent infers to, is the long term commitment they have to the area. This has allowed community residents to move up the economic ladder and become influential assets to the industries previously not seen in boomtown literature due to the shortened time span of the industries presence.

79 year old, white male, retired oil field worker: "Locals have been able to become the middle management of not only the big oil industries but also the service companies. The local community definitely has more wealth due to this.”

The addition of this lucrative industry had definite impacts on the social economic status of local residents. The following respondent discusses a very prominent time for the area economically. He also highlights the common occurrence where local residents were able to fully navigate the professional lad- 
der of the incoming oil industry. Which further strengthens the argument previously discussed that residents of this area, unlike those of boomtown literature, were able to have long-term careers within the industry. Furthermore, he states that many were able to open their own independent businesses.

62 year old, white male, city official: "[The] oil industry in Louisiana has been very good to South Louisiana. At one time there was the largest number of millionaires in South Louisiana than anywhere else. The major industry in the area before oil was the fishing and shrimping industry. A lot of the people who had shrimp boats were contacted by the oil industry and turned their boat into some type of oil supply boat. A lot of the people that went into the oil business were in the shrimping business originally. Many of these businesses grew from one boat to fleets of crew boats."

The presence of the industry had farther stretching positive impacts on community residents than purely increased financial opportunities. The establishment of a new middle class to the area has brought about many positive impacts for community residents that are still seen today and have not waivered during the cyclical expansion and contraction of the industry. The following section will highlight these impacts.

\section{Consequences for Familial/Inter-Generational Mobility and Status Attainment}

The off-shore oil industry's effect on levels of out migration has been widely cited within the literature (Seydlitz et al., 1993, 1995). However, unlike previous literature the current research implicates a positive connotation of outmigration. The off-shore oil industry brought new jobs to the area which had significantly higher incomes than previous occupations present in the area. This provided inhabitants a multitude of other career paths and life choices to which their earlier relatives were not accustomed. Our findings highlight that the industry's presence allowed for increased opportunities for residents' intergenerational mobility through such avenues as increased educational and occupational opportunities. While often the negative aspects of out-migration on communities have been emphasized, our findings suggest a positive long-term consequence on family status attainment.

One outcome was increased avenues of social mobility than were previously found in the area. Many subjects documented this phenomenon especially when examining the social mobility of children of Morgan City and St. Mary Parish.

Interviewer: "How long has your family lived in the Morgan City or St. Mary parish area?”

58 year old, white male, attorney: "Since 1881 and that would be my paternal grandmothers family."

Interviewer: "Do you know what type of work those grandparents did?"

58 year old, white male, attorney: "They were farmers. They raised sugar cane, cotton, corn, and soy beans."

Interviewer: "Do you know how much schooling they had?"

58 year old, white male, attorney: "Most of them were high school graduates. Two of the female ancestors, my grandmother and her sister had some college."

Interviewer: "How much schooling have you had?"

58 year old, white male, attorney: "I am an attorney and I have a degree in accounting. I worked on my masters in business administration and received a law degree. I don’t know, a lot of years.”

Interviewer: "Do you know what type of work your relatives did and what type of schooling they had?"

44 year old, white female, administrative assistant: "I'll start with the grandparents. On my father's side, none of them had a real job. They trapped and fished, basically lived off the land. [Respondent's grandparents] never owned a car. I don't know if they went to school, I doubt it. Their son, who is my father, he went to the $7^{\text {th }}$ or $8^{\text {th }}$ grade. Then he had to quit school to help out with the trapping."

Interviewer: "How much schooling have you had?"

44 year old, white female, administrative assistant: “[I] graduated Morgan City High School in 1979. Married, stayed home for 13 years. Went back to school, got my associates degree. This was probably 8 years ago. [Works as an administrative assistant at an oil service company].”

Interviewer: "Do you have any children or grandchildren that still live in the area?"

44 year old, white female, administrative assistant: "Yes, I have two children. I have a 23 year old son that also works for [an oil service company]. He was a diver, he now works in Lafayette. I have a 17 year old who is a senior at Central Catholic.”

These quotes give examples of a transition among the population from relatively lower class occupations such as trapping and farming to a more industrial job base. This transition brought with it increased opportunities for social mobility of the residents of the area. With this transition the area also witnessed increases in levels of income, education, civic and social organizations, and population (Brown, 2010).

Respondents also narrate residents becoming more aware of diversified life choices during this time period. With increases in education and income, many residents of Morgan City began to broaden their career and social horizons. In the following quote a respondent explains that residents became aware of different experiences based on their interactions with newcomers brought in by the off-shore oil industry.

53 year old, white female, environmental activist: "I think that the [oil field] engineers and all brought in experiences that the people of Morgan City didn't have. I think that the resistance to getting a job outside [of St. Mary Parish] was due to the lack of a college education. I graduated first in my class; three of us went to college. The rest of them, and this is not degrading, were going to work on their fathers shrimp boats or the welding shops. There wasn't even a thought of going to college. So in order to go work outside you need a college education. Now, more from Morgan City attend [Nicholls State University] because Nicholls at that time was just a day college and they ran the buses from Morgan City. More from that area went but again the thought was never to get an education and go somewhere else it was always to get an education and come back; to teach school doing education. And I think when those engineers came in they brought life experiences into the mix that were not there.”

It was during this time that residents of Morgan City and surrounding communities began to diversify many aspects of their personal life. Many respondents cite a large portion of this new phenomenon to be due to the presence of the off-shore oil industry and more importantly its workers. The following quotes emphasize how respondents felt that the introduction of new workers into the area brought with them a new set of "ideas" or culture from which the locals were able to expand their own. 
Interviewer: "How did the community change after the discovery of off shore oil?"

50 year old, white male, business owner: "It is my understanding, that it [Morgan City] was a relatively quiet fishing and shrimping town until the offshore oil industry. It impacted it greatly in the fact that Morgan City became a lot like Florida is now, everyone was from somewhere else. You had a lot of new comers. They set down some roots to where they are now becoming the established citizens. But there were a lot of new people that came down. Here everybody was from somewhere else while at Franklin it has been pretty stable.

Interviewer: "What were these people like?"

50 year old, white male, business owner: "They were protestant which was different. They were better traveled. One thing that I have discovered with Louisiana in general is they don't travel. I think they brought in a lot of new ideas."

52 year old, white male, business vice president: "The pace of life increased. There was a huge influx of people that were not from here. They brought new customs and ideas. It really changed the way of life here."

57 year old, white male, police officer: "I would say probably dramatically. You had people coming in from all areas and that goes on today. People come down here for work. The east end [Morgan City] of the parish obviously has a large transient population. You will find people that have been there for 30 years but they have come there from Mississippi, Arkansas, or Texas. It changes the population especially on the east end of the parish. You have a more diversified people.”

The following quote illustrates a couple of different themes of how the area changed due to the introduction of the off-shore oil industry. The first of which highlights the adoption of new goals by locals. They felt that they had increased opportunity with the emergence of the new industry. Secondly, how new opportunities allowed for intergenerational mobility. While as previous social stratification in the area showed little variation over generations, the introduction of this industry introduced and reinforced a middle class to this area that was up to that point scarcely seen in the area.

Interviewer: "Were people more able to easily obtain personal goals now or before the oil industry?"

58 year old, white male, oil company worker: "After the oil industry because they had more money. I don't know what your goal is, if your goal is to drink enough beer to put you to sleep and keep you sleeping until you wake up whenever you want to, then that's a goal. But if your goal is to give to your children more chances that were offered to you then unless you were a very successful cane farmer, shrimp boat owner, or had a real good trapping lease that was not a possibility. The whole level of what peoples' expectations and goals were changed once the money came. Now the [prominent family] always had money ...Y You had the real rich and the real poor. So either you owned the cane being farmed or you were going out there with a knife to cut it. Either you owned the boat or you were a deckhand. There was no middle class, when the oil company came in the middle class was bigger than both and some of the middle class really became very wealthy after a little while."

The outmigration from the area is not viewed as detrimental by community residents but one of increased opportunities providing the ability for individuals to move away from the area if they choose.

\section{Discussion and Conclusion}

As noted at the beginning of this article one of the industrial features of oil and gas extraction is its cycle of expansion and contraction in supply and demand. It has been suggested this pattern is analogous to boomtowns. While this may be the case for western boomtowns, the social history of Morgan City and the nearby communities of St. Mary Parish indicate otherwise. The boomtown model does not seem to be applicable to offshore oil. If one looks at company/mining towns of the western United States, the concept appears to be relevant. The towns were created due to the emergence of the industry and then subsequently disappeared or nearly did at the completion of extraction. Hence, the term "ghost town" is a feature of the west. Conversely, there are no such created "company towns" and/or abandoned places associated with offshore oil development. The demand for offshore oil has never stopped. This demand has moved up and down over the short run and up over the long term. But the ideology that pervades the oil industry and the community is that the industry will return because the demand is always there. Oil, like many other industries and the jobs associated with it, has varying demand overtime. Members of the community have learned to persist in this cycle. This unsettled character is an expected characteristic of the industry (Luton \& Cluck, 2002; Forsyth \& Gauthier, 1991).

Furthermore, the negative outcomes of boomtown literature were not found in this research. The positive benefits to the area have remained in the area. The local community was able to adapt and incorporate themselves within the industry. This fostered a middle class that still exists in the community today. Along with these positive economic benefits came increased aspirations for the local residents. These diversified worldviews have remained among the community residents.

These individuals experienced greater intergenerational mobility through increased educational and occupational opportunities. The industry brought newcomers to the area who were not appeased by the educational system in place. These individuals, along with locals in the community, asked for curriculum additions. They joined the PTA and through their interaction in it demanded such curricula as Geometry, Calculus, and Fine Art to be offered within the local school system. Secondary education in the area was also positively affected by the industry. Industry leaders were big players in the introduction of a college to the area. This college did not only offer classes specifically for the oil industry but also general education as well.

It was not only through increased educational outlets that residents of the area perceived increased mobility. Respondents illustrated a sense of increased goals and opportunities for themselves as well as others. One way this came through was from direct association with employment in the industry. A theme emerged dictating that this industry infused the area with a middle class. However, residents also illustrated a perception of increased worldviews during this time directly attributed to the introduction of a very heterogeneous group to the community. They state the incoming population brought with it diversity and different lifestyles. Many respondents were introduced to new ways of viewing the world during this time. Many individuals had never thought of college or traveling and became introduced to them through their interactions with the newcomers.

However, one cannot assume the everlasting presence of oil. 
It is true that the off-shore oil industry has a longer time horizon than the ordinary mining industry. However, eventually on a long enough time frame the oil reserves will be depleted. Even before depletion alternate sources of energy or environmental concerns may halt the industry. This could provide for a scenario where socio-economic life in these communities will deteriorate due to a shutdown of the oil industry. Other research seems to lead to a more positive future (Brown, 2010). These communities are not solely reliant upon the off-shore oil industry as seen in many previous western energy extraction towns. The extraction of off-shore petroleum requires extensive service industries which employs and gives livelihoods to many local residents (Doeren, 1978: p. 32). Such companies as supply houses, rental tool companies, oil sale firms, mud companies, truck lines, marine and offshore equipment repair companies and shipyards, all have profited from a symbiotic relationship with oil. These service industries which are primarily locally owned and operated provide for a diversified economy that might be better suited to sustain after the oil industry ceases to dominate the economic landscape.

\section{Limitations of Current Research and Implications for Future Research}

The qualitative nature of the current research of course limits the generalizable nature of the findings. However, the research aimed to counter this aspect of qualitative research by acquiring a large and heterogeneous sample that occupied a fairly large spatial area. With that said the findings could be distinct to the area. Thus, future qualitative research utilizing a diversity of effects model should be established to decipher if these results are found in other communities within the off-shore oil and gas industry.

Also, past research which has looked at community resident's attitudes towards industries which dominate the local economic sector have often found pervasive social support to the industry regardless of its positive or negative social or environmental effects (Altman, Rosenquist et al., 2000). The respondents may have biased viewpoints towards the oil and gas industry due to the vast presence it has within their community. They may in turn be more likely to overlook the negative effects of the industry. Furthermore, due to their own personal incentive for the continuation of the industry and their relationship with it they may embellish the positive nature of the industry. Future research should utilize both qualitative and quantitative methodology to address this issue of possible sample bias. Future research could focus on a random sample of respondents who are not related either directly or indirectly with the off-shore oil industry and examine their attitudes towards it. These findings can then be compared to those within the oil industry to look for contradictions or agreements.

The sample of this study can also be seen as a possible limitation of the research. While steps were taken to provide as generalizable of a sample as possible to the surrounding population this is often a weakness of qualitative methodology. Future research could utilize such non-probability sampling as quota sampling to address this issue. Quantitative measuring techniques could also be employed.

Another consideration that needs to be addressed in future research is current crises with the off-shore oil and gas industry. The recent gulf oil disaster which witnessed the horrifying explosion of an off-shore well and subsequent leak of billions of gallons of oil into the gulf may alter many of the current resident's perceptions of the industries long-term effects to the environment as well as their community. This event may have significant effect on future research findings on those living in affected and non affected areas.

The last major constraint of this study is it significantly low African American sample. The data indicate that African Americans have experienced a very different effect from the offshore oil industry. First, no Africans Americans who had established service companies seemed to benefit from the expansion of OCS activity. Second, few Africans Americans attained supervisory level positions and those that did were often later demoted as the oil industry exchanged hands. For instance, in one such case a man was promoted when newcomers came in and demoted with newcomers left. Third, some had no recognition or experiences with a boom/bust cycle. Things did not get better or worse, indeed their experiences seemed flat. Last, it seems as if few African Americans migrated to the area. During the last several decades Blacks have made progress moving into jobs traditionally reserved for whites. Barriers have been removed and racial differences in the occupations of employed men have substantially decreased, and among women, a continuation of recent trends implies an elimination of racial differences in occupations. Such sweeping generalizations may not describe experiences within particular sectors of oil field employment. The findings within this population suggest a specific need to revisit this research. Further study should examine more systematically the degree to which the substantial fluctuations in the economic environment of South Louisiana's oil patch has interacted with or influenced social biographies and social change among African Americans.

\section{References}

Altman, D., Rosenquist, V. et al. (2000). Churches, tobacco farmers, and community sustainability: Insights from the tobacco South. Journal of Community Psychology, 28, 151-168.

doi:10.1002/(SICI)1520-6629(200003)28:2<151::AID-JCOP4>3.0.C O;2-W

Babbie, E. (2004). The practice of social research. Belmont, CA: Wadsworth Publishing Company.

Becker, H. (1970). The relevance of life histories. In N. K. Denzin (Eds.), Sociological methods: A sourcebook (pp. 419-429). Chicago, Illinois: Aldine Publishing Company

Brabant, S. (1993). The impact of a boom/bust economy on poverty. In S. Laska, V. Baxter, R. Seydlitz, R. Thayer, S. Brabant, \& C. Forsyth (Eds.), Impact of offshore oil exploration and production on the social institutions of coastal Louisiana (pp. 161-194). New Orleans, LA: Minerals Management Service.

Brown, T. (2010). Social change, social capital, and civic community: A qualitative study of the long-term effects of industrial restructuring on a coastal community. Ph.D Thesis, Louisiana State University, Baton Rouge.

Bursik, R. J., \& Grasmick, H. G. (1993). Neighborhoods and crime: The dimensions of effective community control. New York: Lexington Books.

Doeren, S. (1978). The social integrative effects of fairs and festivals on local communities: The shrimp and petroleum festival in Morgan City, LA. Ph.D Thesis, Louisiana State University, Baton Rouge.

Forsyth, C., \& Gauthier, D. (1991). Families of offshore oil workers: Adaptations to cyclical father absence/presence. Sociological Spectrum, 11, 177-201. doi:10.1080/02732173.1991.9981962

Forsyth, C. J., Luthra, A. D., \& Bankston, W. B. (2007). Framing perceptions of oil development and social disruption. The Social Science 
Journal, 44, 287-299. doi:10.1016/j.soscij.2007.03.015

Fowler, I. (1958). Local industrial structures, economic power, and community welfare. Social Problems, 6, 41-51. doi:10.1525/sp.1958.6.1.03a00070

Freudenburg, W. R. (1984). Boomtown's youth: The differential impacts of rapid community growth on adolescents and adults. American Sociological Review, 49, 697-705. doi:10.2307/2095426

Geertz, C. (1973). The interpretation of cultures: Selected essays. New York: Basic Books.

Gramling, B., \& Brabant, S. (1986). Boomtowns and offshore energy impact assessment: The development of a comprehensive model. Sociological Perspectives, 29, 177-201.

Innes, J. E., \& Booher, D. E. (2000). Indicators for sustainable communities: A strategy building on complexity theory and distributed intelligence. Planning Theory and Practice, 1, 173-186. doi:10.1080/14649350020008378

Jackson, J. E., Lee, R. G., \& Sommers, P. (2004). Monitoring the community impacts of Northwest forestland: An alternative to social indicators. Society and Natural Resources, 17, 223-233.

doi:10.1080/08941920490270258

Jacobs, B. A. (2000). Robbing drug dealers: Violence beyond the law. New York: Aldine de Gruyter.

Kasarda, J. D., \& Janowitz, M. (1974). Community attachment in mass society. American Sociological Review, 39, 328-39. doi:10.2307/2094293

Luthra, A. D., Bankston, W. B., Kalich, DeA. M., \& Forsyth, C. J. (2007). Economic fluctuation and crime: A time-series analysis of the effects of oil development in the coastal regions of Louisiana. Deviant Behavior, 28, 113-130. doi:10.1080/01639620601130976

Luton, H., \& Cluck, R. E. (2003) Social impact assessment and offshore oil and gas in the Gulf of Mexico. Unpublished Manuscript

Murdock, S. H. et al. (1984). An assessment of the accuracy and utility of socioeconomic impact assessments. In C. M. Mckell et al. (Ed.), Paradoxes of Western energy development: How can we maintain the land and the people if we develop? (pp. 265-296). CO: Westview Press.

Parsons, T., \& Shils, E. (1951). Toward a general theory of action.
Cambridge, MA: Harvard University Press.

Seydlitz, R., Laska, S., Spain, D., Triche, E. W., \& Bishop, K. L. (1993). Development and social problems: The impact of the offshore oil industry on suicide and homicide rates. Rural Sociology, 58, 93-110. doi:10.1111/j.1549-0831.1993.tb00484.x

Seydlitz, R., \& Laska, S. (1994). Social and economic impacts of petroleum "Boom and Bust" cycles. OCS Study MMS 94-0016. New Orleans, LA: U.S. Department of Interior, Minerals Management Service, Gulf of Mexico OCS Region.

Seydlitz et al. (1995). Economic impacts of energy development. Society and Natural Resources, 8, 321-337. doi:10.1080/08941929509380925

Shaw, C. R., \& McKay, H. D. (1969). Juvenile delinquency in urban areas: A study of rates of delinquency in relation to differential characteristics of local communities in American cities. Chicago, Illinois: University of Chicago Press.

Stone, D. A. (1989). Causal stories and the development of policy agendas. Political Science Quarterly, 104, 281-300. doi:10.2307/2151585

Summers, G. f., \& Selvik, A. (1982). Energy resource communities. Madison, WI: MJM Publishing for the Institute of Industrial Economics.

Tolbert, C. M., Lyson, T. A., \& Irwin, M. D. (1998). Local capitalism, civic engagement and socioeconomic well-being. Social Forces, 77, 401-428. doi:10.2307/3005533

Tolbert, C. M., Irwin, M. D., Lyson, T. A., \& Nucci, A. R. (2002). Civic community in small-town America: How civic welfare is influenced by local capitalism and civic engagement. Rural Sociology, 67, 90-113. doi:10.1111/j.1549-0831.2002.tb00095.x

Tolbert, C. M. II (2006). Sustainable community in oil and gas country: Final report. OCS Study MMS 2006-011. New Orleans, LA: U.S. Department of the Interior, Minerals Management Service, Gulf of Mexico OCS Region.

Toennies, F. (1963). Community and society. New York: Harper Books. Wilkinson, K. P., Thompson, J. G., Reynolds, R. R. Jr., \& Ostresh, L. M. (1982). Local social disruption and Western energy development. Pacific Sociological Review, 25, 275-296. 